\title{
Cytotoxicity evaluation of calcium hypochlorite and other commonly used root canal irrigants against human gingival fibroblast cells: An in vitro evaluation
}

\author{
Jerry Jose ${ }^{A-D}$, Ajitha Palanivelu ${ }^{C, E, F}$, Haripriya Subbaiyan ${ }^{\mathrm{E}, \mathrm{F}}$ \\ Department of Conservative Dentistry and Endodontics, Saveetha Dental College, Saveetha Institute of Medical and Technical Sciences, Chennai, India \\ A - research concept and design; $\mathrm{B}$ - collection and/or assembly of data; C - data analysis and interpretation; \\ $D$ - writing the article; $E$ - critical revision of the article; $F$ - final approval of the article
}

Address for correspondence
Jerry Jose
E-mail: jerryjosekavungal@gmail.com

Funding sources

None declared

Conflict of interest

None declared

Received on May 27, 2020

Reviewed on August 10, 2020

Accepted on September 14, 2020

Published online on March 31, 2021

Cite as

Jose J, Palanivelu A, Subbaiyan H. Cytotoxicity evaluation of calcium hypochlorite and other commonly used root canal irrigants against human gingival fibroblast cells: An in vitro evaluation. Dent Med Probl. 2021;58(1):31-37. doi:10.17219/dmp/127522

DOI

$10.17219 / \mathrm{dmp} / 127522$

Copyright

๑ 2021 by Wroclaw Medical University

This is an article distributed under the terms of the

Creative Commons Attribution 3.0 Unported License (CC BY 3.0)

(https://creativecommons.org/licenses/by/3.0/).

\begin{abstract}
Background. The conventional endodontic therapy primarily focuses on biomechanical preparation, which is achieved by the application of various intracanal irrigants and intracanal medicaments. One of the most commonly used intracanal irrigants - sodium hypochlorite $(\mathrm{NaOCl}$ - has already been proven to have an antimicrobial effect as well as the ability to dissolve tissues in the areas where files cannot reach. One of the recently used irrigants having a promising effect is calcium hypochlorite $\left(\mathrm{Ca}(\mathrm{OCl})_{2}\right)$, which has been shown to be relatively more stable than $\mathrm{NaOCl}$ and has much more chlorine ions.

Objectives. The aim of this study was to assess the individual cytotoxicity of various root canal irrigants and the combined cytotoxicity of $\mathrm{NaOCl}$ and $\mathrm{Ca}(\mathrm{OCl})_{2}$ with ethylenediaminetetraacetic acid (EDTA) against human gingival fibroblast (hGF) cells.

Material and methods. The evaluation of the individual cytotoxicity was carried out with regard to the following root canal irrigants: $\mathrm{NaOCl} ; \mathrm{Ca}(\mathrm{OCl})_{2}$; and chlorhexidine (CHX). The evaluation of the combined cytotoxicity regarded $\mathrm{NaOCI} / \mathrm{EDTA}$ and $\mathrm{Ca}(\mathrm{OC})_{2} / \mathrm{EDTA}$. The concentrations used were $0.025 \%, 0.050 \%$, $0.10 \%$, and $0.20 \%$. The cytotoxicity against hGF cells was examined within a timeframe of $6 \mathrm{~h}$ and $24 \mathrm{~h}$ with the use of the sulforhodamine B (SRB) assay.

Results. It was observed that $\mathrm{Ca}(\mathrm{OCl})_{2}$ had a mean absorbance rate of $0.315 \pm 0.02,0.294 \pm 0.03,0.265$ \pm 0.03 , and $0.240 \pm 0.02$ at $0.025 \%, 0.050 \%, 0.10 \%$, and $0.20 \%$, respectively. In combination with EDTA, the mean absorbance rate was $70.12 \pm 2.9,67.42 \pm 4.3,64.35 \pm 3.6$, and $61.58 \pm 4.1$ at $0.025 \%, 0.050 \%$, $0.10 \%$, and $0.20 \%$, respectively. The cytotoxic effect of the root canal irrigants on hGF cells was observed to be statistically significant $(p<0.05)$.

Conclusions. Calcium hypochlorite is less cytotoxic than $\mathrm{NaOCl}$, and when used in combination with EDTA, it was shown to have its cytotoxic effect on hGF cells reduced to a great extent.
\end{abstract}

Key words: chlorhexidine, EDTA, endodontics, root canal irrigants, sodium hypochlorite 


\section{Introduction}

The typical aim in the endodontic therapy is to perform the optimal disinfection of the root canal system, after which a suitable filling material is placed in this disinfected space, preventing any further ingress of microorganisms leading to further complications. ${ }^{1}$ It is well known that microorganisms are a critical factor in the development of pulp and periapical diseases, and have an influence on the prognosis of the endodontic therapy in the long run. ${ }^{2,3}$ Currently, along with mechanical instrumentation, various adjuvants, such as intracanal irrigants and intracanal medicaments are used, which helps to significantly reduce the amount of microorganisms. Due to the complexity of the root canal anatomy, intracanal irrigants are of great importance in the endodontic procedure, since they have the ability to get into the sites where mechanical instrumentation fails to reach. ${ }^{4}$

Various intracanal irrigants have been used in the conventional endodontic therapy in the past decades in order to help the clinician to completely eradicate microbes, necrotic tissues and debris from the root canal system, the most common being chlorhexidine (CHX) and sodium hypochlorite $(\mathrm{NaOCl})$, which have been shown to have an antimicrobial effect, the ability to inactivate endotoxins as well as the ability to remove some part of the smear layer and necrotic tissue remnants. ${ }^{5}$ Sodium hypochlorite, one of the most common intracanal irrigants, also shows antimicrobial activity and is able to dissolve pulpal tissue remnants in spaces such as fins and ramifications, where instrumentation cannot reach. ${ }^{6}$ The capability of $\mathrm{NaOCl}$ to dissolve pulpal tissue results from its alkaline nature as well as from the release of $\mathrm{HOCl}^{-}$and $\mathrm{OCl}^{-}$ions. ${ }^{7}$

Sodium hypochlorite is known to show certain drawbacks, such as the lack of substantivity, the ability to dissolve only the organic portions of the smear layer and a cytotoxic effect when extruded into the periapical region. One of the ways to overcome these drawbacks is to use it in combination with ethylenediaminetetraacetic acid (EDTA), which reduces the $\mathrm{pH}$ of $\mathrm{NaOCl}$ in a timedependent manner as well as the amount of the available free chlorine, making $\mathrm{NaOCl}$ more stable and preventing the weakening of the dentinal matrix. ${ }^{8}$ One of the recently introduced intracanal irrigants of a promising potential is calcium hypochlorite $\left(\mathrm{Ca}(\mathrm{OCl})_{2}\right)$, which has shown an antimicrobial effect and at the same time a much higher chlorine release in comparison with $\mathrm{NaOCl} .^{9}$ These irrigants have been reported to affect various cells present in the periapical complex. Although numerous assessments of their cytotoxicity against multiple cell lines have been performed, there is no data available in the dental literature on the cytotoxic effect of these irrigants on human gingival fibroblast (hGF) cells. The current study aimed to evaluate the individual cytotoxic activity of various root canal irrigants, and the combined cytotoxicity of $\mathrm{NaOCl}$ and $\mathrm{Ca}(\mathrm{OCl})_{2}$ with EDTA against hGF cells.

\section{Material and methods}

This in vitro study had received prior approval of the institutional review board (No. SRB/SDC/ENDO-1805/20/04).

\section{Preparation of the cell line}

This in vitro study was conducted under aseptic conditions in a research laboratory. The hGF cell lines were received from the National Centre for Cell Science, Pune, India. The hGF cells were seeded in the $\alpha$-minimal essential medium ( $\alpha$-MEM) containing $10 \%$ fetal bovine serum (FBS), $100 \mathrm{IU} / \mathrm{mL}$ penicillin, $2.5 \mu \mathrm{g} / \mathrm{mL}$ streptomycin, $2.5 \mu \mathrm{g} / \mathrm{mL}$ amphotericin $\mathrm{B}$, and $50 \mu \mathrm{g} / \mathrm{mL}$ ascorbic acid, which was replaced twice a week, and incubated in 5\% $\mathrm{CO}_{2}$ at $37^{\circ} \mathrm{C}$ for humidification.

\section{Preparation of calcium hypochlorite and other irrigants}

The $\mathrm{CaOH}_{2}$ powder of $65 \%$ purity (Merck, Darmstadt, Germany) was weighed on a precision balance and mixed with distilled and sterilized water. When the solutions were completely dissolved, they were filtered twice to remove debris, and then stored in bottles. Other chemicals used in the study were as follows: $\mathrm{NaOCl}$ (Molychem, Mumbai, India); EDTA (Thermo Fisher Scientific, Waltham, USA); and CHX (Sigma-Aldrich, St. Louis, USA).

\section{Experimental groups}

The individual cytotoxicity evaluation was done in 4 groups:

- group A: $10 \% \mathrm{NaOCl}$ diluted to $0.025 \%, 0.050 \%, 0.10 \%$, and $0.20 \%$;

- group B: $10 \% \mathrm{Ca}(\mathrm{OCl})_{2}$ diluted to $0.025 \%, 0.050 \%$, $0.10 \%$, and $0.20 \%$;

- group C: $2 \%$ CHX diluted to $0.025 \%, 0.050 \%, 0.10 \%$, and $0.20 \%$;

- group D: the growth medium used as a control group.

For the combined cytotoxicity evaluation, 2 groups were analyzed:

- group A: $10 \% \mathrm{NaOCl}$ diluted to $0.025 \%, 0.050 \%, 0.10 \%$, and $0.20 \%$, mixed with EDTA;

- group B: $10 \% \mathrm{Ca}(\mathrm{OCl})_{2}$ diluted to $0.025 \%, 0.050 \%$, $0.10 \%$, and $0.20 \%$, mixed with EDTA.

\section{Cytotoxicity test with the sulforhodamine B} assay

The cytotoxicity test was performed using a modification of the method developed by Vichai and Kirtikara. ${ }^{10}$ The assessment was carried out within a timeframe of $6 \mathrm{~h}$ and $24 \mathrm{~h}$, with each concentration being tested in triplicate. The microtiter plates were incubated with Dulbecco's Modified Eagle's Medium (DMEM) 
(Life Technologies, Grand Island, USA) supplemented with $10 \% \mathrm{FBS}, 100 \mu \mathrm{L} /$ well of the culture medium, for $24 \mathrm{~h}$ at $37^{\circ} \mathrm{C}$ with $5 \% \mathrm{CO}_{2}$. After $24 \mathrm{~h}$ of incubation, cell adhesion and growth were observed. The cellular concentration used was $1.4 \times 104$ cells $/ \mathrm{mL}$. The medium was then discarded, and the treatment group samples, controls and DMEM without FBS were added to each well. After $24 \mathrm{~h}$ of incubation, the cells were fixed with trichloroacetic acid (TCA) $(100 \mu \mathrm{L} /$ well $)$ and placed under refrigeration for $1 \mathrm{~h}$ at $4^{\circ} \mathrm{C}$. Trichloroacetic acid was then removed, and the plates were washed in low-flow water 3 times and dried. After that, the plates were stained for $20 \mathrm{~min}$ at room temperature with sulforhodamine B (SRB) (Sigma-Aldrich) $0.4 \%$ (50 $\mu \mathrm{L} /$ well). The plates were washed with $1 \%$ acetic acid solution and dried at room temperature. The unbound dye was removed after washing; the dye bound to the protein was solubilized in the basic medium to determine the optical density in a plate reader set at $570 \mathrm{~nm}$. The colorimetric evaluation gives an estimate of total protein mass. The cellular concentration used was $1.4 \times 104$ cells $/ \mathrm{ml}$. The percentage of living cells for each concentration of the tested substances was assessed with the following equation (Equation 1):

percentage of cells survived $=\frac{(\mathrm{Abs} \mathrm{T}-\mathrm{AbsC})}{(\mathrm{AbsC})} \times 100$

where:

AbsT - average absorbance of the tested substances;

AbsC - average absorbance of the control.

\section{Statistical analysis}

The statistical analysis was carried out using IBM SPSS for Windows, v. 21.0 (IBM Corp., Armonk, USA) The one-way analysis of variance (ANOVA) was applied to assess differences in absorbance at $570 \mathrm{~nm}$ at different time intervals between the treatment groups, post-hoc Tukey's test was used for the intergroup comparison of absorbance between the test groups; the independent $t$ test was done to assess cell viability at different time points between the groups. The level of significance was set at $p<0.05$.

\section{Results}

The experiments were carried out in triplicate. The results of the assessment of cytotoxicity against hGF cells are shown in a dose-dependent and time-dependent manner, with a total timeframe of $6 \mathrm{~h}$ and $24 \mathrm{~h}$. They are presented as mean $(M) \pm$ standard deviation $(S D)$.

Table 1 shows the absorbance values for different root canal irrigants at different concentrations at $6 \mathrm{~h}$ and $24 \mathrm{~h}$. Table 2 presents the percentage of cell viability for different root canal irrigants at different concentrations at $6 \mathrm{~h}$ and $24 \mathrm{~h}$. The findings of the study suggest that $\mathrm{CHX}, \mathrm{NaOCl}$ and $\mathrm{Ca}(\mathrm{OCl})_{2}$ had an effect on hGF cells $(p=0.001)$. Figure 1 shows the dose-dependent effect of various root canal irrigants on hGF cells at $6 \mathrm{~h}$. The intergroup analysis of the rate of absorbance at the $0.025 \%$ concentration showed statistically significant differences in various combinations: $\mathrm{NaOCl}$ vs $\mathrm{Ca}(\mathrm{OCl})_{2}$ $(p=0.002) ; \mathrm{NaOCl}$ vs negative control $(\mathrm{NC})(p=0.001)$; $\mathrm{Ca}(\mathrm{OCl})_{2}$ vs $\mathrm{CHX}(p=0.013)$; and $\mathrm{CHX}$ vs $\mathrm{NC}(p=0.001)$.

Table 1. Absorbance values for various root canal irrigants at different concentrations at $6 \mathrm{~h}$ and $24 \mathrm{~h}$

\begin{tabular}{|c|c|c|c|c|c|c|c|c|}
\hline \multirow{2}{*}{ Irrigant } & \multicolumn{4}{|c|}{ Absorbance at $570 \mathrm{~nm}$ at $6 \mathrm{~h}$} & \multicolumn{4}{|c|}{ Absorbance at $570 \mathrm{~nm}$ at $24 \mathrm{~h}$} \\
\hline & $0.025 \%$ & $0.050 \%$ & $0.10 \%$ & $0.20 \%$ & $0.025 \%$ & $0.050 \%$ & $0.10 \%$ & $0.20 \%$ \\
\hline $\mathrm{NaOCl}$ & $0.125 \pm 0.04$ & $0.129 \pm 0.01$ & $0.105 \pm 0.01$ & $0.052 \pm 0.01$ & $0.286 \pm 0.02$ & $0.258 \pm 0.01$ & $0.222 \pm 0.05$ & $0.202 \pm 0.04$ \\
\hline $\mathrm{Ca}(\mathrm{OCl})_{2}$ & $0.315 \pm 0.02$ & $0.294 \pm 0.03$ & $0.265 \pm 0.03$ & $0.240 \pm 0.02$ & $0.498 \pm 0.06$ & $0.468 \pm 0.02$ & $0.424 \pm 0.03$ & $0.390 \pm 0.03$ \\
\hline $\mathrm{CHX}$ & $0.175 \pm 0.03$ & $0.148 \pm 0.02$ & $0.112 \pm 0.1$ & $0.098 \pm 0.02$ & $0.312 \pm 0.09$ & $0.238 \pm 0.04$ & $0.221 \pm 0.06$ & $0.192 \pm 0.05$ \\
\hline $\mathrm{NC}$ & $0.392 \pm 0.04$ & $0.388 \pm 0.03$ & $0.381 \pm 0.04$ & $0.396 \pm 0.05$ & $0.512 \pm 0.03$ & $0.507 \pm 0.03$ & $0.512 \pm 0.04$ & $0.512 \pm 0.05$ \\
\hline
\end{tabular}

$\mathrm{NaOCl}$ - sodium hypochlorite; $\mathrm{Ca}(\mathrm{OCl})_{2}$ - calcium hypochlorite; $\mathrm{CHX}$ - chlorhexidine; $\mathrm{NC}$ - negative control.

Data presented as mean $(M) \pm$ standard deviation $(S D)$.

Table 2. Cell viability for various root canal irrigants at different concentrations at $6 \mathrm{~h}$ and $24 \mathrm{~h}$

\begin{tabular}{|c|c|c|c|c|c|c|c|c|}
\hline \multirow{2}{*}{ Irrigant } & \multicolumn{4}{|c|}{ Percentage of viable cells [\%] at $6 \mathrm{~h}$} & \multicolumn{4}{|c|}{ Percentage of viable cells [\%] at $24 \mathrm{~h}$} \\
\hline & $0.025 \%$ & $0.050 \%$ & $0.10 \%$ & $0.20 \%$ & $0.025 \%$ & $0.050 \%$ & $0.10 \%$ & $0.20 \%$ \\
\hline $\mathrm{NaOCl}$ & $52.78 \pm 2.6$ & $41.89 \pm 1.6$ & $32.60 \pm 2.5$ & $20.80 \pm 1.4$ & $51.78 \pm 4.3$ & $48.56 \pm 2.6$ & $39.89 \pm 2.8$ & $23.82 \pm 2.1$ \\
\hline $\mathrm{Ca}(\mathrm{OCl})_{2}$ & $69.89 \pm 1.8$ & $60.23 \pm 3.4$ & $53.99 \pm 1.6$ & $50.16 \pm 2.4$ & $56.64 \pm 5.6$ & $50.11 \pm 0.6$ & $42.71 \pm 3.1$ & $28.15 \pm 1.9$ \\
\hline $\mathrm{CHX}$ & $79.35 \pm 3.2$ & $71.54 \pm 2.4$ & $68.21 \pm 3.8$ & $70.25 \pm 3.9$ & $70.25 \pm 6.4$ & $63.58 \pm 3.1$ & $59.96 \pm 4.6$ & $53.89 \pm 4.3$ \\
\hline NC & $100.00 \pm 9.6$ & $100.00 \pm 8.2$ & $100.00 \pm 7.5$ & $100.00 \pm 5.7$ & $100.00 \pm 8.1$ & $100.00 \pm 2.6$ & $100.00 \pm 8.3$ & $100.00 \pm 9.1$ \\
\hline
\end{tabular}

Data presented as mean $(M) \pm$ standard deviation $(S D)$. 
The comparison of absorbance at the $0.050 \%$ concentration showed statistically significant differences in the following cases: $\mathrm{NaOCl}$ vs $\mathrm{Ca}(\mathrm{OCl})_{2}(p=0.001) ; \mathrm{NaOCl}$ vs $\mathrm{NC}$ $(p=0.001) ; \mathrm{Ca}(\mathrm{OCl})_{2}$ vs $\mathrm{CHX}(p=0.001) ; \mathrm{Ca}(\mathrm{OCl})_{2}$ vs $\mathrm{NC}$ $(p=0.001)$; and CHX vs NC $(p=0.001)$. At the $0.10 \%$ concentration, differences in absorbance were observed to be statistically significant for $\mathrm{NaOCl}$ vs $\mathrm{Ca}(\mathrm{OCl})_{2}(p=0.001)$, $\mathrm{NaOCl}$ vs $\mathrm{NC}(p=0.001), \mathrm{Ca}(\mathrm{OCl})_{2}$ vs $\mathrm{CHX}(p=0.001)$, $\mathrm{Ca}(\mathrm{OCl})_{2}$ vs NC $(p=0.002)$, and $\mathrm{CHX}$ vs NC $(p=0.001)$. At the $0.20 \%$ concentration, the comparison of absorbance showed statistically significant differences for $\mathrm{NaOCl}$ vs $\mathrm{Ca}(\mathrm{OCl})_{2}(p=0.001), \mathrm{NaOCl}$ vs NC $(p=0.001), \mathrm{Ca}(\mathrm{OCl})_{2}$ vs $\mathrm{CHX}(p=0.005), \mathrm{Ca}(\mathrm{OCl})_{2}$ vs NC $(p=0.006)$, and $\mathrm{CHX}$ vs NC $(p=0.001)$.

Figure 2 shows the dose-dependent effect of various root canal irrigants on hGF cells at $24 \mathrm{~h}$. The comparison of the absorbance of various irrigants at $0.025 \%$ showed statistically significant differences for the following: $\mathrm{NaOCl}$ vs $\mathrm{Ca}(\mathrm{OCl})_{2}(p=0.004) ; \mathrm{NaOCl}$ vs $\mathrm{NC}$

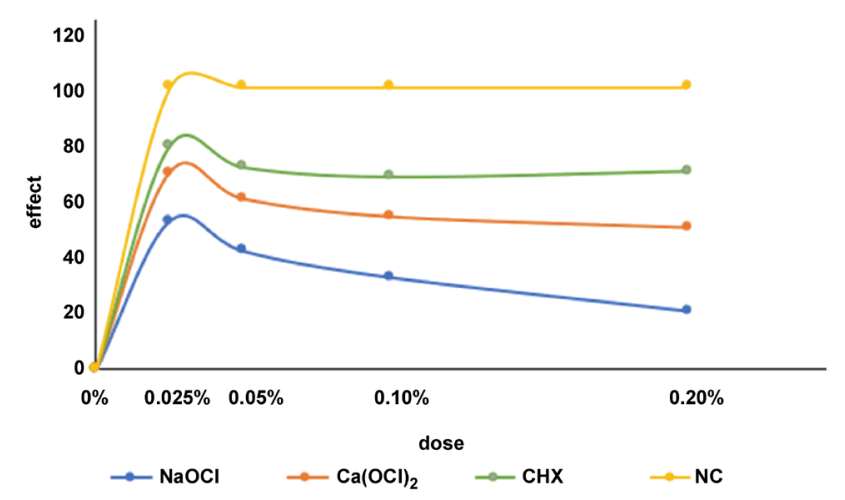

Fig. 1. Dose-effect plot of sodium hypochlorite ( $\mathrm{NaOCl})$, calcium hypochlorite $\left(\mathrm{Ca}(\mathrm{OCl})_{2}\right)$ and chlorhexidine $(\mathrm{CHX})$ at $6 \mathrm{~h}$ against human gingival fibroblast (hGF) cells (sulforhodamine B (SRB) assay)

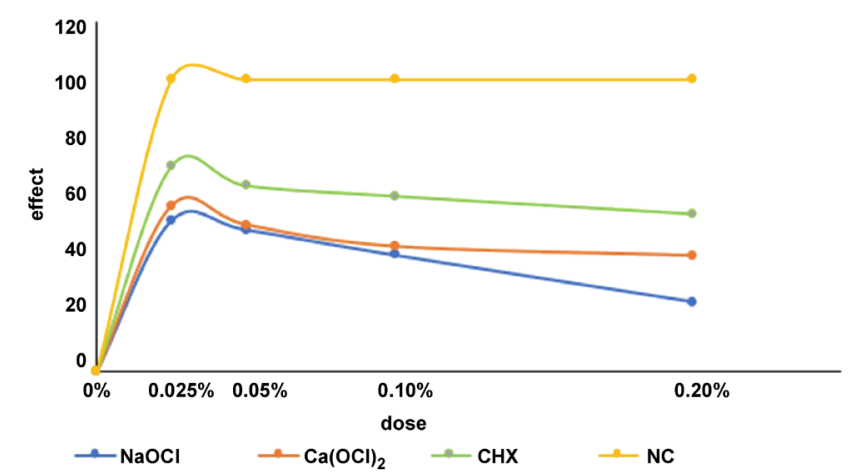

Fig. 2. Dose-effect plot of sodium hypochlorite ( $\mathrm{NaOCl}$ ), calcium hypochlorite $\left(\mathrm{Ca}(\mathrm{OCl})_{2}\right)$ and chlorhexidine $(\mathrm{CHX})$ at $24 \mathrm{~h}$ against human gingival fibroblast (hGF) cells (sulforhodamine B (SRB) assay) $(p=0.003) ; \mathrm{Ca}(\mathrm{OCl})_{2}$ vs $\mathrm{CHX}(p=0.004), \mathrm{Ca}(\mathrm{OCl})_{2}$ vs $\mathrm{NC}(p=0.003), \mathrm{Ca}(\mathrm{OCl})_{2}$ vs $\mathrm{NC}(p=0.008)$, and $\mathrm{CHX}$ vs $\mathrm{NC}(p=0.005)$. At the $0.050 \%$ concentration, the comparison of absorbance showed statistically significant differences for $\mathrm{NaOCl}$ vs $\mathrm{Ca}(\mathrm{OCl})_{2}(p=0.002), \mathrm{NaOCl}$ vs $\mathrm{NC}(p=0.001), \mathrm{Ca}(\mathrm{OCl})_{2}$ vs $\mathrm{CHX}(p=0.001)$, and $\mathrm{CHX}$ vs $\mathrm{NC}(p=0.001)$. At the $0.10 \%$ concentration, the intergroup comparison of absorbance showed statistically significant differences for $\mathrm{NaOCl}$ vs $\mathrm{Ca}(\mathrm{OCl})_{2}$ $(p=0.001), \mathrm{NaOCl}$ vs $\mathrm{NC}(p=0.001), \mathrm{Ca}(\mathrm{OCl})_{2}$ vs $\mathrm{CHX}$ $(p=0.001)$, and $\mathrm{CHX}$ vs $\mathrm{NC}(p=0.001)$. In the case of the $0.20 \%$ concentration, the intergroup absorbance rate was observed to be statistically significantly different for $\mathrm{NaOCl}$ vs $\mathrm{Ca}(\mathrm{OCl})_{2}(p=0.008), \mathrm{NaOCl}$ vs $\mathrm{NC}$ $(p=0.001), \mathrm{Ca}(\mathrm{OCl})_{2}$ vs CHX $(p=0.008), \mathrm{Ca}(\mathrm{OCl})_{2}$ vs $\mathrm{NC}(p=0.006)$, and CHX vs NC $(p=0.001)$.

Table 3 shows the percentage of cell viability for hGF cells post reaction with $\mathrm{NaOCl} / \mathrm{EDTA}$ and $\mathrm{Ca}(\mathrm{OCl})_{2} /$ EDTA at different concentrations at $6 \mathrm{~h}$ and $24 \mathrm{~h}$. Table 4 presents the final concentrations of $\mathrm{NaOCl}$ and $\mathrm{Ca}(\mathrm{OCl})_{2}$ after serial dilution with EDTA at $6 \mathrm{~h}$ and $24 \mathrm{~h}$. Figure 3 depicts the combined cytotoxicity against hGF cells at $6 \mathrm{~h}$ of the combinations of $\mathrm{NaOCl} /$ EDTA and $\mathrm{Ca}(\mathrm{OCl})_{2} /$ EDTA. The comparison of cell viability done at $6 \mathrm{~h}$ showed statistically significant difference between $\mathrm{NaOCl} /$ EDTA and $\mathrm{Ca}(\mathrm{OCl})_{2} /$ EDTA at $0.025 \%(p=0.001), 0.050 \%(p=0.001), 0.10 \%$ $(p=0.001)$, and $0.20 \%(p=0.001)$. Figure 4 shows the combined cytotoxicity against hGF cells at $24 \mathrm{~h}$ for the combinations of $\mathrm{NaOCl} /$ EDTA and $\mathrm{Ca}(\mathrm{OCl})_{2} /$ EDTA. The comparison of cell viability done at $24 \mathrm{~h}$ showed statistically significant difference between $\mathrm{NaOCl} / \mathrm{EDTA}$ and $\mathrm{Ca}(\mathrm{OCl})_{2} / \mathrm{EDTA}$ at $0.025 \%(p=0.019), 0.050 \%$ $(p=0.007), 0.10 \%(p=0.005)$, and $0.20 \%(p=0.029)$.

Table 4. Final concentration after serial dilution with ethylenediaminetetraacetic acid (EDTA) at $6 \mathrm{~h}$ and $24 \mathrm{~h}$

\begin{tabular}{|c|cc|}
\hline Time $[\mathrm{h}]$ & $\mathrm{NaOCI} / \mathrm{EDTA}$ & $\mathrm{Ca}(\mathrm{OCl})_{2} / \mathrm{EDTA}$ \\
\hline \multirow{3}{*}{6} & $0.025 / 0.1$ & $0.005 / 0.2$ \\
& $0.050 / 0.2$ & $0.012 / 0.3$ \\
& $0.100 / 0.3$ & $0.025 / 0.4$ \\
& $0.200 / 0.4$ & $0.037 / 0.5$ \\
24 & $0.037 / 0.01$ & $0.015 / 0.05$ \\
& $0.015 / 0.02$ & $0.037 / 0.04$ \\
& $0.023 / 0.03$ & $0.050 / 0.03$ \\
& $0.041 / 0.04$ & $0.075 / 0.02$ \\
\hline
\end{tabular}

Table 3. Cell viability at $6 \mathrm{~h}$ and $24 \mathrm{~h}$ in combination with ethylenediaminetetraacetic acid (EDTA) (sulforhodamine B (SRB) assay)

\begin{tabular}{|c|c|c|c|c|c|c|c|c|}
\hline \multirow{2}{*}{$\begin{array}{l}\text { Combination } \\
\text { of irrigant/EDTA }\end{array}$} & \multicolumn{4}{|c|}{ Percentage of viable cells [\%] at $6 \mathrm{~h}$} & \multicolumn{4}{|c|}{ Percentage of viable cells [\%] at $24 \mathrm{~h}$} \\
\hline & $0.025 \%$ & $0.050 \%$ & $0.10 \%$ & $0.20 \%$ & $0.025 \%$ & $0.050 \%$ & $0.10 \%$ & $0.20 \%$ \\
\hline $\mathrm{NaOCl} / \mathrm{EDTA}$ & $51.24 \pm 3.1$ & $50.43 \pm 2.3$ & $39.43 \pm 3.1$ & $30.56 \pm 1.9$ & $50.12 \pm 2.1$ & $41.89 \pm 3.5$ & $34.16 \pm 2.4$ & $28.49 \pm 2.9$ \\
\hline $\mathrm{Ca}(\mathrm{OCl})_{2} / \mathrm{EDTA}$ & $70.86 \pm 4.5$ & $66.89 \pm 5.8$ & $64.32 \pm 2.8$ & $63.47 \pm 2.8$ & $70.12 \pm 2.9$ & $67.42 \pm 4.3$ & $64.35 \pm 3.6$ & $61.58 \pm 4.1$ \\
\hline
\end{tabular}

Data presented as mean $(M) \pm$ standard deviation (SD). 


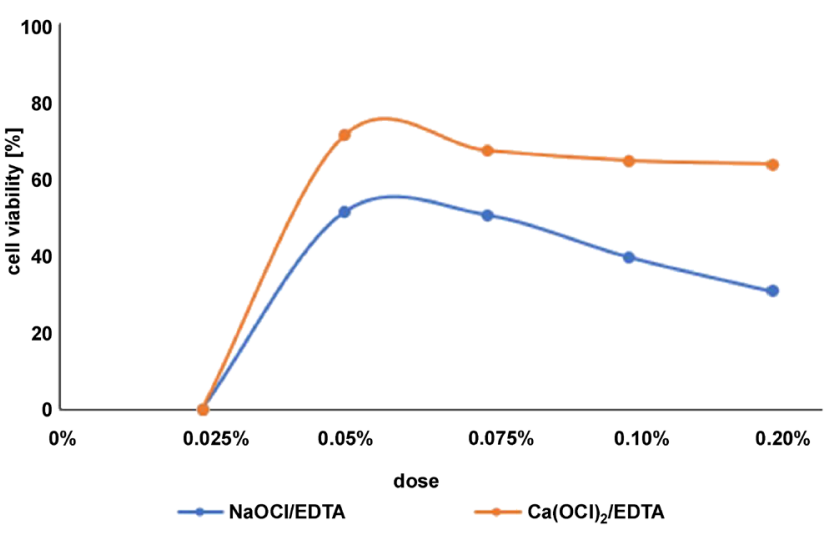

Fig. 3. Dose-cell viability plot of sodium hypochlorite $(\mathrm{NaOCl})$ with ethylenediaminetetraacetic acid (EDTA) and calcium hypochlorite $\left(\mathrm{Ca}(\mathrm{OCl})_{2}\right)$ with EDTA at $6 \mathrm{~h}$ against human gingival fibroblast (hGF) cells (sulforhodamine B (SRB) assay)

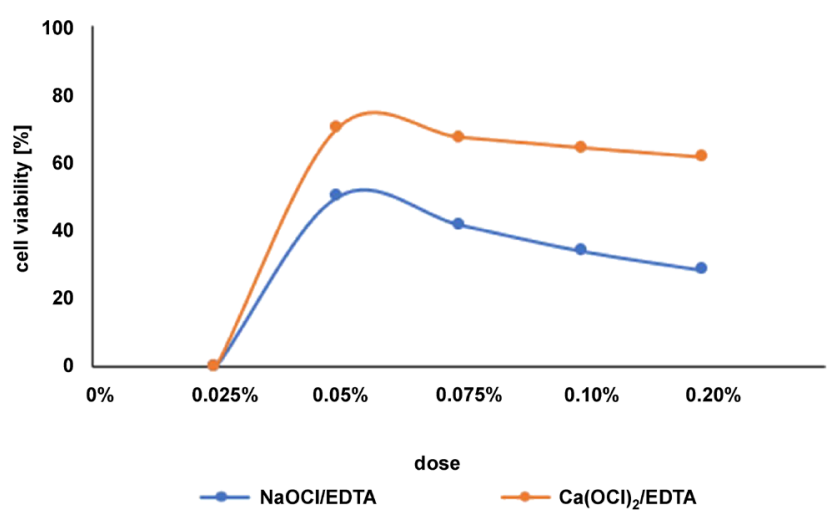

Fig. 4. Dose-cell viability plot plot of sodium hypochlorite ( $\mathrm{NaOCl})$ with ethylenediaminetetraacetic acid (EDTA) and calcium hypochlorite $\left(\mathrm{Ca}(\mathrm{OCl})_{2}\right)$ with EDTA at $24 \mathrm{~h}$ against human gingival fibroblast (hGF) cells (sulforhodamine B (SRB) assay)

\section{Discussion}

Root canal irrigants have a pivotal role in the success of the endodontic therapy. It is well known that they participate in removing necrotic tissue and debris from fins and ramifications, where mechanical instrumentation cannot reach. Still, there is a risk that during the endodontic procedure, intracanal irrigants will be extruded periapically. ${ }^{11}$ This can cause damage to cells and also impair wound healing. ${ }^{12}$ Another potential effect of the extrusion of irrigants is that they may impair the survival of stem cells, which are required for successful tissue regeneration. ${ }^{13}$

Human gingival fibroblast cells are reported to have a much higher reparative potential than human periodontal ligament fibroblasts (hPDLF). ${ }^{14}$ Though hPDLF cells could simulate periodontal ligament fibroblasts better, they are known to produce a higher amount of collagen than hGF cells, and could potentially influence the results of cytotoxicity for the materials tested. ${ }^{15}$ Apart from having great regenerative properties as compared to other fibroblasts, hGF cells also have the multilineage capability to differentiate into different types of cells, such as osteoblasts and periodontal ligament cells, which can be potentially used for periodontal tissue engineering. ${ }^{16}$ The presence of lipopolysaccharides in endodontic pathogens has an immunosuppressive effect on the human pulp, leading to pulpal pain and periapical inflammation. ${ }^{17}$ Unlike other cells present in the periodontium, hGF cells do not express lipopolysaccharide tolerance and have been shown to release inflammatory cytokines for up to 7 days, which makes them the least susceptibile to microbial action. ${ }^{18}$

As compared to other standard cell lines, hGF cells are diploid host cells, continuous in nature, with the specialized properties retained; they are more likely to demonstrate the cytotoxic effect exerted by dental materials on cells than other commercially available cell lines, which are aneuploid in nature, showing a heteroploid chromosome pattern and responding differently to different materials. ${ }^{19}$ The use of commercially available standardized cell lines has an advantage that they are easily accessed, but can demonstrate greater toxicity levels and show an altered effect of the use of dental materials as compared to specific lineage cell lines, which are more desirable, as they bridge the gap between in vitro and in vivo biocompatibility. ${ }^{20}$

Various studies have already been done in the field of endodontics, using hGF cells. Barnhart et al. assessed the cytotoxicity of various intracanal irrigants with the CyQUANT $^{\circledR}$ assay and found potassium iodide and calcium hydroxide to be the least cytotoxic against hGF cells. ${ }^{21}$ Lee et al. also evaluated the cytotoxicity of various dental adhesives against hGF cells and found that all of the tested adhesives had a cytotoxic effect on hGF cells. ${ }^{22}$

In the present study, the SRB assay was used for the cytotoxicity assessment, as it has been shown to have a higher sensitivity; the cell viability count is not affected by any compounds released from the specimen, is independent of any cellular metabolic action, which makes the assay much easier to conduct in comparison with other assay methods. ${ }^{23}$

Calcium hypochlorite is another intracanal irrigant introduced in endodontics which has been shown to have a good antimicrobial activity. ${ }^{24-26}$ Though it is very similar to $\mathrm{NaOCl}$ in terms of chemical action, the presence of more chlorine $\left(\mathrm{Cl}^{-}\right)$in $\mathrm{Ca}(\mathrm{OCl})_{2}$ results in more pronounced antimicrobial action and a greater tissue dissolving capability as compared to $\mathrm{NaOCl} .{ }^{27}$ The current study showed the least cytotoxic effect in the case of CHX. It is known that $\mathrm{CHX}$ has a sustained antimicrobial activity as well as low toxicity, but its major disadvantage is its inability to dissolve organic pulp tissues. ${ }^{28}$

The present study showed that $\mathrm{Ca}(\mathrm{OCl})_{2}$ maintained the viability of cells when tested within a timeframe of $6 \mathrm{~h}$ and $24 \mathrm{~h}$. In contrast, $\mathrm{NaOCl}$ was proven to decrease the levels of viable hGF cells after $24 \mathrm{~h}$ even further. In an in vitro study, Coaguila-Llerena et al. found that differences in cytotoxicity against L929 and hPDLF cells between $\mathrm{Ca}(\mathrm{OCl})_{2}$ and 2\% CHX were statistically insignificant; also, the cellular proliferation capacity was maintained when $\mathrm{Ca}(\mathrm{OCl})_{2}$ at a concentration of $2.5 \%$ was used. ${ }^{29}$ In another study, 
Ferraz Blattes et al. conducted an in vitro cytotoxicity assessment against 3T3 fibroblasts and an analysis of the inflammatory reaction in rats; the authors reported that $\mathrm{Ca}(\mathrm{OCl})_{2}$ showed lower levels of inflammation, better healing response as well as lower cytotoxicity as compared to $\mathrm{NaOCl} .^{30}$

The combined use of $\mathrm{NaOCl}$ with EDTA is the recommended protocol to be followed according to the American Association of Endodontists (AAE) guidelines and was the basis for evaluating the combined cytotoxic effect in our study. It is known that $\mathrm{NaOCl} /$ EDTA acts on the organic/ inorganic portion of the smear layer present in dentin and shows a synergistic effect by chelating $\mathrm{Ca}^{2+}$ ions, causing collagen deproteinization, which results in a superficial change in dentin, preventing further microbial colonization. ${ }^{31}$ The present study also showed that cytotoxicity was reduced to a greater extent with the addition of EDTA. Our results are consistent with those obtained by Vouzara et al., who proved that the application of the combination of $\mathrm{NaOCl}$ and EDTA reduced the cytotoxic effect against MRC5 cells. ${ }^{32}$ The results obtained in our study could be due to an antagonizing effect of EDTA on $\mathrm{NaOCl}$, which plays a critical role in reducing its $\mathrm{pH}$ in a time-dependent manner as well as decreasing exponentially the amount of the released chlorine gas. ${ }^{33}$ Due to the chemically similar nature, the same action could be justified in the case of $\mathrm{Ca}(\mathrm{OCl})_{2}$ as well.

\section{Limitations}

One of the limitations of the present study is not using an in vivo model to assess the cytotoxic reaction, since an in vitro model is an ideally conditioned environment and may not necessarily transmit the achieved results in vivo. Another limitation is probably the use of lower concentrations of irrigants, which were diluted further to different levels for assessment standardization and may not necessarily show the same result when used in their clinically recommended concentrations.

\section{Conclusions}

Based on the present study, it can be concluded that $\mathrm{Ca}(\mathrm{OCl})_{2}$ showed less cytotoxicity in a time-dependent and dose-dependent manner than $\mathrm{NaOCl}$, but was more cytotoxic against hGF cells in comparison with chlorhexidine gluconate. The combined use of $\mathrm{Ca}(\mathrm{OCl})_{2}$ and $\mathrm{NaOCl}$ with EDTA showed a more significant reduction of cytotoxicity against hGF cells. In contrast, the sustainability of hGF cells after $24 \mathrm{~h}$ was much greater in the case of using $\mathrm{Ca}(\mathrm{OCl})_{2}$ as compared to $\mathrm{NaOCl}$.

\section{ORCID iDs}

Jerry Jose (D) https://orcid.org/0000-0003-4555-7171

Ajitha Palanivelu (D) https://orcid.org/0000-0003-4985-697X

Haripriya Subbaiyan (D) https://orcid.org/0000-0002-3419-6350

\section{References}

1. Burry JC, Stover S, Eichmiller F, Bhagavatula P. Outcomes of primary endodontic therapy provided by endodontic specialists compared with other providers. J Endod. 2016;42(5):702-705. doi:10.1016/j. joen.2016.02.008

2. Fouad AF. Endodontic microbiology and pathobiology: Current state of knowledge. Dent Clin North Am. 2017;61(1):1-15. doi:10.1016/j.cden.2016.08.001

3. Siqueira JF Jr., Rôças IN. Microbiology of apical periodontitis. In: $\varnothing$ rstavik D, ed. Essential Endodontology. Prevention and Treatment of Apical Periodontitis. $3^{\text {rd }}$ ed. John Wiley \& Sons, Ltd.; 2019:91-142. doi:10.1002/9781119272014.ch4

4. Prada I, Micó-Muñoz P, Giner-Lluesma T, Micó-Martínez P, MuwaquetRodríguez S, Albero-Monteagudo A. Update of the therapeutic planning of irrigation and intracanal medication in root canal treatment. A literature review. J Clin Exp Dent. 2019;11(2):e185-e193. doi: $10.4317 /$ jced. 55560

5. Gonçalves LS, Val Rodrigues RC, Andrade CV Jr., Soares RG, Vettore MV. The effect of sodium hypochlorite and chlorhexidine as irrigant solutions for root canal disinfection: A systematic review of clinical trials. J Endod. 2016;42(4):527-532. doi:10.1016/j.joen.2015.12.021

6. Borzini L, Condò R, De Dominicis P, Casaglia A, Cerroni L. Root canal irrigation: Chemical agents and plant extracts against Enterococcus faecalis. Open Dent J. 2016;10:692-703. doi:10.2174/1874210601610010692

7. Tartari T, Bachmann L, Alvez Maliza AG, Andrade FB, Hungaro Duarte MA, Bramante CM. Tissue dissolution and modifications in dentin composition by different sodium hypochlorite concentrations. J Appl Oral Sci. 2016;24(3):291-298. doi:10.1590/1678775720150524

8. Mohammadi Z, Shalavi S, Moeintaghavi A, Jafarzadeh H. A review over benefits and drawbacks of combining sodium hypochlorite with other endodontic materials. Open Dent J. 2017;11:661-669. doi:10.2174/1874210601711010661

9. Sedigh-Shams M, Gholami A, Abbaszadegan A, et al. Antimicrobial efficacy and cytocompatibility of calcium hypochlorite solution as a root canal irrigant: An in vitro investigation. Iran Endod J. 2016;11(3):169-174. doi:10.7508/iej.2016.03.004

10. Vichai V, Kirtikara K. Sulforhodamine B colorimetric assay for cytotoxicity screening. Nat Protoc. 2006;1(3):1112-1116. doi:10.1038/ nprot.2006.179

11. Silva PB, Krolow AM, Pilownic KJ, et al. Apical extrusion of debris and irrigants using different irrigation needles. Braz Dent J. 2016;27(2):192-195. doi:10.1590/0103-6440201600382

12. Mangum LC, Franklin NA, Garcia GR, Akers KS, Wenke JC. Rapid degradation and non-selectivity of Dakin's solution prevents effectiveness in contaminated musculoskeletal wound models. Injury. 2018;49(10):1763-1773. doi:10.1016/j.injury.2018.08.004

13. Kim SG, Kahler B, Lin LM. Current developments in regenerative endodontics. Curr Oral Health Rep. 2016;3(4):293-301. doi:10.1007/ s40496-016-0109-8

14. Mariotti A, Cochran DL. Characterization of fibroblasts derived from human periodontal ligament and gingiva. J Periodontol. 1990;61(2):103-111. doi:10.1902/jop.1990.61.2.103

15. Peltola M, SaloT, Oikarinen K. Toxic effects of various retrograde root filling materials on gingival fibroblasts and rat sarcoma cells. Endod Dent Traumatol. 1992;8(3):120-124. doi:10.1111/j.1600-9657.1992. tb00448.x

16. Lee IK, Lee MJ, Jang HS. The interrelationship between human gingival fibroblast differentiation and cultivating time. Tissue Eng Regen Med. 2013;10(2):60-64. doi:10.1007/s13770-013-0371-y

17. Lakshmi Narayanan L, Vaishnavi C. Endodontic microbiology. J Conserv Dent. 2010;13(4):233-239. doi:10.4103/0972-0707.73386

18. Ara T, Kurata $K$, Hirai $K$, et al. Human gingival fibroblasts are critical in sustaining inflammation in periodontal disease. J Periodontal Res. 2009;44(1):21-27. doi:10.1111/j.1600-0765.2007.01041.x

19. Eldeniz AU, Mustafa K, Ørstavik D, Dahl JE. Cytotoxicity of new resin-, calcium hydroxide- and silicone-based root canal sealers on fibroblasts derived from human gingiva and L929 cell lines. Int Endod J. 2007;40(5):329-337. doi:10.1111/j.1365-2591.2007.01211.x 
20. Thonemann B, Schmalz G, Hiller KA, SchweikI H. Responses of L929 mouse fibroblasts, primary and immortalized bovine dental papilla-derived cell lines to dental resin components. Dent Mater. 2002;18(4):318-323. doi:10.1016/s0109-5641(01)00056-2

21. Barnhart BD, Chuang A, Dalle Lucca JJ, Roberts S, Liewehr F, Joyce AP. An in vitro evaluation of the cytotoxicity of various endodontic irrigants on human gingival fibroblasts. J Endod. 2005;31(8):613-615. doi:10.1097/01.don.0000153840.94227.87

22. Lee Y, Ahn JS, Yi YA, et al. Cytotoxicity of four denture adhesives on human gingival fibroblast cells. Acta Odontol Scand. 2015;73(2):87-92. doi:10.3109/00016357.2014.954266

23. Orellana EA, Kasinski AL. Sulforhodamine B (SRB) assay in cell culture to investigate cell proliferation. Bio Protoc. 2016;6(21):e1984. doi:10.21769/BioProtoc.1984.

24. Dumani A, Guvenmez HK, Yilmaz S, Yoldas O, Bek Kurklu ZG. Antibacterial efficacy of calcium hypochlorite with Vibringe sonic irrigation system on Enterococcus faecalis: An in vitro study. Biomed Res Int. 2016;2016:8076131. doi:10.1155/2016/8076131

25. e Silva Leonardo NG, Carlotto IB, Luisi SB, Poli Kopper PM, Grecca FS, Montagner F. Calcium hypochlorite solutions: Evaluation of surface tension and effect of different storage conditions and time periods over pH and available chlorine content. J Endod. 2016;42(4):641-645. doi:10.1016/j.joen.2016.01.006

26. de Paula KB, Carlotto IB, Marconi DF, Cardosso Ferreira MB, Grecca FS, Montagner F. Calcium hypochlorite solutions - an in vitro evaluation of antimicrobial action and pulp dissolution. Eur Endod J. 2019;4(1):15-20. doi:10.14744/eej.2018.64936

27. Soligo LT, Lodi E, Farina AP, Souza MA, Pimento Vidal CdM, Cecchin D. Antibacterial efficacy of synthetic and natural-derived novel endodontic irrigant solutions. Braz Dent J. 2018;29(5):459-464. doi:10.1590/0103-6440201802172

28. Nourzadeh M, Amini A, Fakoor F, Raoof M, Sharififar F. Comparative antimicrobial efficacy of Eucalyptus galbie and Myrtus communis $L$. extracts, chlorhexidine and sodium hypochlorite against Enterococcus faecalis. Iran Endod J. 2017;12(2):205-210. doi:10.22037/iej.2017.40

29. Coaguila-Llerena H, Rodrigues EM, Tanomaru-Filho M, GuerreiroTanomaru JM, Faria G. Effects of calcium hypochlorite and octenidine hydrochloride on L929 and human periodontal ligament cells. Braz Dent J. 2019;30(3):213-219. doi:10.1590/0103-6440201902280

30. Ferraz Blattes GB, Mestieri LB, Böttcher DE, Medeiros Fossati AC Montagner F, Grecca FS. Cell migration, viability and tissue reaction of calcium hypochlorite based-solutions irrigants: An in vitro and in vivo study. Arch Oral Biol. 2017;73:34-39. doi:10.1016/j.archoralbio.2016.08.037

31. Tartari T, Oda DF, Zancan RF, et al. Mixture of alkaline tetrasodium EDTA with sodium hypochlorite promotes in vitro smear layer removal and organic matter dissolution during biomechanical preparation. Int Endod J. 2017;50(1):106-114. doi:10.1111/iej.12595

32. Vouzara T, Koulaouzidou E, Ziouti F, Economides N. Combined and independent cytotoxicity of sodium hypochlorite, ethylenediaminetetraacetic acid and chlorhexidine. Int Endod J. 2016;49(8):764-773. doi:10.1111/iej.12517

33. Krishnan U, Saji S, Clarkson R, Lalloo R, Moule AJ. Free active chlorine in sodium hypochlorite solutions admixed with octenidine, SmearOFF, chlorhexidine, and EDTA. J Endod. 2017;43(8):1354-1359. doi:10.1016/j.joen.2017.03.034 